\title{
Application of exploratory factor analysis to assess fish consumption in a university community
}

\author{
Aplicação de análise fatorial exploratória para avaliar o consumo de pescado em uma comunidade universitária
}

Erika da Silva MACIEL ${ }^{1 *}$, Luciana Kimie SAVAY-DA-SILVA ${ }^{1}$, Júlia Santos VASCONCELOS ${ }^{1}$, Juliana Antunes GALVÃO ${ }^{1}$, Jaqueline Girnos SONATI² ${ }^{2}$, Dirceu da SILVA², Marília OETTERER ${ }^{1}$

\begin{abstract}
The objective of this research was to use the technique of Exploratory Factor Analysis (EFA) for the adequacy of a tool for the assessment of fish consumption and the characteristics involved in this process. Data were collected during a campaign to encourage fish consumption in Brazil with the voluntarily participation of members of a university community. An assessment instrument consisting of multiple-choice questions and a five-point Likert scale was designed and used to measure the importance of certain attributes that influence the choice and consumption of fish. This study sample was composed of of 224 individuals, the majority were women (65.6\%). With regard to the frequency of fish consumption, $37.67 \%$ of the volunteers interviewed said they consume the product two or three times a month, and $29.6 \%$ once a week. The Exploratory Factor Analysis (EFA) was used to group the variables; the extraction was made using the principal components and the rotation using the Quartimax method. The results show clusters in two main constructs, quality and consumption with Cronbach Alpha coefficients of 0.75 and 0.69 , respectively, indicating good internal consistency.
\end{abstract}

Keywords: fish consumption; quality of life; questionnaire; exploratory factor analysis.

\section{Resumo}

O objetivo desta pesquisa foi utilizar-se da técnica de Análise Fatorial Exploratória (AFE) para a adequação de instrumento de avaliação do consumo de pescado e as características envolvidas nesse processo. A coleta de dados ocorreu durante campanha de incentivo ao consumo de pescado no Brasil e contou com a participação de membros de uma comunidade universitária. Foi construído e utilizado um instrumento de avaliação composto por questões de múltipla escolha e em escala Likert de cinco pontos para avaliar a importância de determinados atributos no processo de aquisição e consumo de pescado. A amostra contou com a participação de 224 pessoas, sendo a sua maioria (65,6\%) composta por mulheres. Quanto à frequência de consumo de pescado, 37,67\% dos voluntários entrevistados responderam que consomem o produto de duas a três vezes ao mês e $29,6 \%$, uma vez na semana. A AFE foi utilizada para agrupamento das variáveis, utilizou-se a extração pelos componentes principais e a rotação pelo método Quartimax. Os resultados demonstram agrupamento em dois constructos principais, qualidade e consumo, que apresentaram valores de 0,75 e 0,69, respectivamente, para o Coeficiente Alfa de Cronbach, indicando boa consistência interna. Palavras-chave: consumo de pescado; qualidade de vida; questionário; análise fatorial exploratória.

\section{Introduction}

Regular consumption of fish is part of a healthy diet, which is one of the main reasons for its consumption (VERBEKE; VACKIER, 2005).

Dietary intervention indicates a better quality of life with the use of diets based on fish, fruits, and vegetables (BLANK et al., 2007). Traditional eating habits in Mediterranean populations, for example, offer, among other foods, the choice of fish consumption, with which there is consistent evidence of healthpromoting properties (MUNÕZ et al., 2009; TYROVOLAS; PANAGIOTAKOS, 2010).

A systematic review of publications from 1985 to 2009 on dietary habits and risk of cardiovascular diseases and cancer identified that the adoption of the model Mediterranean diet is associated with reduced risk of cardiovascular diseases and some types of cancer (TYROVOLAS; PANAGIOTAKOS, 2010).
Given that nutritional dietary habits have a fundamental effect on health, it is not surprising that a quality diet is an issue to be addressed by public authorities.

The global fish consumption has been increasing in recent years and factors such as concern with food quality and frequent food-related problems may be influencing this behavior. It appears that the concern with the consumption of foods low on fat and cholesterol and of high nutritional value has contributed to the increase in fish consumption (MICHELS; PROCHMANN, 2002).

Among the benefits of a fish-based diet are the reduction of cholesterol levels and the low incidence of stroke, heart diseases, and Alzheimer's disease. Fish consumption can improve cognitive function in adults and prevent the birth of underweight infants as well as preterm delivery birth (BURGER, 2008).

Received 21/6/2012

Accepted 31/10/2012 (005749)

${ }^{1}$ Escola Superior de Agricultura "Luiz de Queiroz" - ESALQ, Universidade de São Paulo - USP, CEP 13418-900, Piracicaba, SP, Brasil, e-mail: erikasmaciel@gmail.com

2 Universidade Estadual de Campinas - UNICAMP, CEP 13083-970, Campinas, SP, Brasil

${ }^{*}$ Corresponding author

DOI: http://dx.doi.org/10.1590/S0101-20612013005000016 
Knowledge about differences in consumer perceptions of health benefits regarding fish consumption is essential for the development of specific health interventions associated with a dietary choice (DIJK et al., 2011).

Low consumption of fish and fish products, however, is still common in many countries and may be linked to cultural differences (PIENIAK; VERBEKE; SCHOLDERER, 2010), influences of the social environment (TUU et al., 2008), convenience in preparation (OLSEN et al., 2007), high prices, and problems in the production chain (OETTERER, 2002).

The campaign to encourage fish consumption, "Semana do Peixe" (Fish Week), was a project created in Brazil by the Ministry of Fisheries and Aquaculture (MFA) - aimed to increase the consumption of fish and fish products highlighting the benefits that a fish-based diet brings to health in addition to making consumers aware of quality, choice, and preparation of fish (BRASIL, 2010a).

The average of per capita fish consumption in the world is $16.4 \mathrm{~kg}$ per year. However, there is a significant difference between the per capita consumption when the countries' economic conditions are considered, for example, $23.9 \mathrm{~kg}$ of fish per person/year in developed countries; $27.3 \mathrm{~kg}$ in industrialized countries; $11.9 \mathrm{~kg}$ in countries with transition economies; $14.4 \mathrm{~kg}$ in developing countries, and $13.8 \mathrm{~kg}$ in low-income countries facing with food shortages. In South America, the consumption is $8.5 \mathrm{~kg}$ per capita (FOOD..., 2009).

In Brazil, according to the Ministry of Fisheries and Aquaculture (MPA), fish production between 2003 and 2009 grew by $25.2 \%$ amounting $1,240,813$ tons in 2009 . The per capita consumption in 2009 was $9.03 \mathrm{~kg} /$ year, below the rate recommended by the World Health Organization (WHO) of $12 \mathrm{~kg} /$ year; however, it showed growth when compared to the per capita consumption in $2003-6.46 \mathrm{~kg} /$ person/ year - representing an increase of $40 \%$ over the last seven years. The apparent per capita consumption is calculated based on data about the national production, which includes imports and excludes exports, and the resulting number is divided by the total population in the country (BRASIL, 2010b).

The complexity to identify fish consumption and the divergence of available data justify the development of sampling tools that are reliable and can be replicated.

The aim of this study was to use the technique of Exploratory Factor Analysis (EFA) for the adequacy of a tool to assess fish consumption and the characteristics involved in this process during the "Semana do Peixe" (Fish Week) in the city of Piracicaba, Brazil, within a university community.

The EFA is a technique of interdependence that provides tools to analyze the structure of interrelationships (correlations) among a large number of variables (HAIR JUNIOR et al., 2009); it is widely used in food questionnaires to determine consumption patterns and the items that are interrelated (ALVES et al., 2006). The main purpose of FA is to reduce a large number of observed variables to a smaller number of factors. The factors, in turn, are the linear combination of variables (HAIR JUNIOR et al. 2009; FIGUEIREDO FILHO; SILVA JUNIOR, 2010).

This method comprises of propositions that present a similar trend of statistical correlation (COOPER; SCHINDLER, 2003). Accordingly, the validation process involves checking the validity of a test and its ability to measure what is proposed (ANASTASI; URBINA, 2000). It is also a test of accuracy and appropriateness of an elaborate interpretation. In other words, it reports the objectiveness of the test measurements as well as inferences that can be made from the results.

\section{Materials and methods}

\subsection{Sampling and interview structure}

During the celebration of "Semana do Peixe" (Fish Week) in 2009, the Study and Extension Group on Technological Innovation and Fish Quality (GETEP), Department of Agroindustry, Food and Nutrition, College of Agriculture "Luiz de Queiroz” (ESALQ), University of São Paulo (USP), conducted a survey of fish consumption with volunteers from the Campus "Luiz de Queiroz".

The subjects consisted of university students (graduates and undergraduates) and staff who, after being made aware of the Term of Consent - TCLE ("Termo de Consentimento Livre e Esclarecido"), responded voluntarily to a structured interview. Data collection was performed by the previously trained GETEP team. This study was approved by the Ethics Committee for Research with Humans, ESALQ-USP protocol 046. There was no public identification of the respondents.

For the interviews, a structured questionnaire was a designed with multiple-choice questions using a 5-point Likert scale (MALHOTRA, 2006).

The questionnaire was developed based on the literature available that shows obstacles for fish consumption (OETTERER, 2002; TRONDSEN et al., 2003; ZHOU, 2004; HONKANEN; OLSEN; VERPLANKEN, 2005; VERBEKE; VACKIER, 2005; WEI, ZENG, 2005; OLSEN, 2007; BURGER, 2008; SONODA, 2007; MACIEL et al., 2009). These points were clustered, and the items in the tool according to a five-point Likert scale ranging from zero (1) to extreme (5) referring to the fish attributes and characteristics of importance for fish consumption. The questionnaire was subjected to analysis by a team of expert researchers in the fish sector and statistics and nutrition areas, who verified the content and structure of the items. After incorporating suggestions, an analysis was carried out with the team of researchers, the questionnaire was applied. The questionnaire was applied to a university community and the invitations were made individually by researchers who presented the aims of the research and the questions of the instrument. The participation was voluntary and individualized. Respondents were free to sign or not the TCLE and provide information. The data were processed using spreadsheet software aiming to build a dataset that was then subjected to statistical analysis. 


\subsection{Statistical analysis}

\section{Exploratory factor analysis}

The responses were coded into the spreadsheet software SPSS 15.0 (Statistical Package of The Social Sciences) and subjected to the descriptive statistical analyses; all variables were tested by the Kolmogorov-Smirnov goodness-of-fit test, which was used to assess data adherence to the normal distribution or of Gauss, EFA, and Cronbach Alpha Coefficient for all constructs derived from the factor analysis.

To understand how the Likert scale variables relate and group to form the constructs, an exploratory factor analysis was conducted. For that purpose, the data were examined according to Hair Junior et al. (2009) in terms of normality, collinearity, and distribution of outliers.

Tests of Kaiser-Meyer-Olkin (KMO) and Bartlett sphericity were used to determine the level of confidence that can be expected when using EFA on data (HAIR JUNIOR et al., 2009).

The KMO test presents normalized values (between 0 and $1.0)$ and shows the proportion of common variance of the variables (items of the instrument used), or what percentage of the variables is accounted for by common factors. To interpret the results, values close to 1.0 indicate that the factor analysis method is perfectly suited for data processing. On the other hand, values below 0.5 indicate the inadequacy of the method (STATISTICAL..., 1999).

The Bartlett test of sphericity is based on the statistical distribution of chisquare and tests the null hypothesis, i.e., no correlation between the variables. Levels of significance greater than 0.100 indicate that the data are not suitable for the treatment with the method in question; in this case, the null hypothesis cannot be rejected.

\section{Extraction analysis}

One of the statistical approaches in extracting factors is principal components analysis; the factors with eigenvalues (own values) $>1.0$ and factorial loads $>0.4$ were used as consideration criteria. The results were also combined with the orthogonal methods of rotation Varimax, Quartimax and Equamax.

The Principal Component Analysis (PCA) was performed in four stages. The extraction process using PCA is used to make combinations uncorrelated to the observed variables (corrigidouncorrelated). The first component has maximum variance. Successive components explain progressively smaller portions of the variance and are all correlated with each other. The EFA is a technique that does not limit to a single solution. Therefore, to perform the analysis, two basic principles were considered in each extraction stage of variables, namely the Parsimonies, which explains the correlations between the observed variables using the smallest number of factors possible, and principle of Interpretability, which preconizes that the factors have a meaning in the context studied, keeping a logical coherence to themselves.
In addition, during the extraction stage of variables, the values of KMO tests and Barlett sphericity, the assessment of the KMO test for each variable, the value of communalities, the logical sense between factors, the stability and finally, the best factorial model.

The minimum of 0.50 was used as the acceptable limit of KMO (HAIR JUNIOR et al., 2009). The values of the four stages of $\mathrm{KMO}$ and the communalities of each variable were assessed. In stages with two factors with communalities below 0.50 , one item was removed at a time, and the result was checked for the next step.

The analysis of anti-image correlation matrix and commonalities were conducted. The anti-image correlation matrix represents the partial correlations between variables after the factorial analysis, which indicates the level at which factors explain the results to one another (HAIR JUNIOR et al., 2009). The commonality represents the proportion of variance of each variable included in the analysis (SCHAWB, 2010).

\section{Rotation analysis}

After eliminating the problematic variables associated to the lower level of commonality, an analysis of the unrotated matrix was conducted to observe the factor loadings for each variable and identify the ones that have high factor loadings in multiple components (constructs) (FIGUEIREDO FILHO; SILVA JUNIOR, 2010). The methods used were orthogonal (Varimax, Equamax, Quartimax) and were tested in combination with principal components extraction.

\section{Cronbach's alpha coefficients}

The Cronbach's Alpha Coefficients were used to assess the reliability of the scale, i.e., the level at which the measurement is error-free and, therefore, presents consistent results (HAIR JUNIOR et al., 2009).

\section{Results}

224 volunteers (average age of $23.8( \pm 6.8)$ years old) were interviewed. The results of sample characterization were based on their relationship with the university, gender, and marital status.

With regard to the relationship to the university, the majority $(77.7 \%)$ is represented by undergraduate students $(\mathrm{n}=174), 16.5 \%$ graduate students $(\mathrm{n}=37), 4.5 \%$ faculty and staff $(\mathrm{n}=10)$, and $1.3 \%$ missing response $(\mathrm{n}=3)$.

As for the gender and marital status, $65.6 \%$ are female $(\mathrm{n}=147)$ and $33.9 \%$ male $(\mathrm{n}=76)$, and are $88.8 \%$ single $(\mathrm{n}=199), 9.3 \%$ married or in a steady and stable relationship $(\mathrm{n}=18), 0.9 \%$ divorced $(\mathrm{n}=3)$, and $0.4 \%$ widowed $(\mathrm{n}=1)$, and one missing response case.

With regard to the frequency of fish consumption, 37.67\% of the volunteers interviewed said they consume the product two or three times a month; $29.6 \%$ once a week; $17.05 \%$ once a month; $12.11 \%$ two or more times a week and $3.59 \%$ reported being non- consumers of fish. The main reasons for not eating 
fish are the fact that they do not like fish (37\%) and the difficulty in its preparation (24\%).

When asked about their usual place of consumption, $56.76 \%$ mentioned their homes and $30.63 \%$ restaurants, and $63.06 \%$ of the volunteers reported that they eat fish at the university restaurant.

A regular weekly consumption of fish by respondents (41.71\%) was verified, which may be attributed to consumption of fish at the university restaurant.

As for fish purchase, the majority (86.22\%) said they buy it at supermarkets. Their preference is for the product packed in trays containing few units (44.09\%), followed by those who prefer to buy in bulk (40\%). Regarding conservation, $65 \%$ said they preferred to buy the frozen product.

The results of the responses about frequency were used to analyze the main characteristics that affect the decision to purchase and consume fish (Table 1).

The Kolmogorov-Smirnov test was used to assess data adherence to the normal distribution or of Gauss. This test showed that the value of significance ( $p$ ) for all variables is lower than $0.001(\mathrm{p}<0.001)$, indicating that the data on the samples cannot be considered normal and therefore should be treated with non-parametric methods (STATISTICAL..., 1999).

Under these conditions, Dillon and Goldstein (1984) and Johnson and Wichern (2000) suggest that the reduction of variables by the factor analysis (FA) method can be used to reduce variables and create factors or variables deriving from linear combinations. However, the mere suggestion of a method cannot be accepted when it comes to analyzing quantitative data; two tests must be considered so that whether to use of the method above mentioned can be decided (HAIR JUNIOR et al., 2009). These authors recommend performing the index analysis of KMO and Bartlett's test of sphericity (BTS).

The use of the EFA allowed defining the constructs and their groupings. The adjustment steps are described below. The extraction by principal components, principal axis factoring, and alpha factoring were tested; the method of principal components showed the best results. The exclusion of variables was tested to the best fit point, i.e., the point at which the variance was explained and the adjustment of the load factor was found. Table 2 shows the values of the adjustment stages.

As can be seen in step 1, although KMO showed good indicators, only $58.5 \%$ of data variance was explained; ideally it should be above $60 \%$. In this case, the variable "Availability in the usual places of purchase" (0.36) was discarded, and the data were subjected to further analysis.

In step 2, with the removal of the variable "Availability in the usual places of purchase", the value of KMO becomes 0.74 , although lower than the previous one, it lies within the acceptable range, and the explained variance increases to $61.79 \%$. However, considering the analysis of the commonalities, there is a low value $(0.38)$ for the variable "packaging". This variable was discarded from the model, and data were subjected to further analysis.

With the removal of the variable "packaging", the KMO value remained 0.74 . In this model, the variance is explained at $65.11 \%$, and in the analysis of commonality only the variables, "smell" (0.47) and "nutritional value" (0.49) had values below 0.50 . The variable "smell" was discarded, and data were subjected to further analysis.

After the removal of the variable "smell", the KMO was 0.71 and the commonality analysis showed that all variables were above 0.50 , and the variance explained was $68.13 \%$, ending, therefore, the method of extraction.

On that basis, the need to calculate the rotation of the variables in relation to the components extracted was identified in order to help visualize the relationship between the variables and constructs. The results showed that the Quartimax method presents the best fit. This extraction method minimizes the number of factors needed to explain each variable and simplifies the interpretation of the obtained variables (HAIR JUNIOR et al., 2009).

Table 1. Frequency of responses to evaluate the characteristics related to purchase and consumption of fish.

\begin{tabular}{|c|c|c|c|c|c|}
\hline \multirow{2}{*}{ How important are the following attributes? } & \multicolumn{5}{|c|}{ Responses scale } \\
\hline & Zero (\%) & Very little (\%) & Medium (\%) & Very much (\%) & Extremelly (\%) \\
\hline Flavor & 1.34 & 1.34 & 7.14 & 41.96 & 48.21 \\
\hline Size & 8.93 & 26.79 & 47.32 & 14.73 & 2.23 \\
\hline Smell & 0.89 & 5.36 & 13.84 & 34.38 & 45.54 \\
\hline Color & 2.23 & 5.80 & 15.18 & 41.07 & 35.71 \\
\hline Texture & 2.26 & 3.17 & 17.19 & 37.10 & 40.27 \\
\hline Packaging & 4.50 & 7.21 & 28.38 & 38.29 & 21.62 \\
\hline Price & 0.90 & 4.07 & 25.79 & 43.89 & 25.34 \\
\hline Nutritional value & 6.79 & 10.41 & 27.60 & 33.48 & 21.72 \\
\hline Brand & 14.55 & 27.27 & 36.82 & 17.73 & 3.64 \\
\hline Origin & 4.55 & 8.64 & 28.64 & 31.36 & 26.82 \\
\hline Availability in the usual places of purchase & 3.15 & 9.01 & 28.83 & 42.34 & 16.67 \\
\hline Stamp of Quality Control - SIF & 9.82 & 8.48 & 11.61 & 29.02 & 41.07 \\
\hline "Green" fish - produced in an environmentally friendly fishery & 8.04 & 11.16 & 25.89 & 25.00 & 29.91 \\
\hline
\end{tabular}


Table 2. Adjustment stages.

\begin{tabular}{|c|c|c|c|c|}
\hline \multirow{2}{*}{ How important is } & \multicolumn{4}{|c|}{ Commonalities } \\
\hline & Stage 1 & Stage 2 & Stage 3 & Stage 4 \\
\hline & $\mathrm{KMO}=0.75$ & $\mathrm{KMO}=0.74$ & $\mathrm{KMO}=0.74$ & $\mathrm{KMO}=0.71$ \\
\hline Variance explained in the factorial model & $58.5 \%$ & $61.79 \%$ & $65.11 \%$ & $68.13 \%$ \\
\hline Flavor & 0.581 & 0.569 & 0.577 & 0.675 \\
\hline Size & 0.652 & 0.653 & 0.749 & 0.745 \\
\hline Smell ${ }^{*}$ & 0.472 & 0.473 & 0.476 & - \\
\hline Packaging* & 0.356 & 0.386 & - & - \\
\hline Price & 0.794 & 0.895 & 0.847 & 0.851 \\
\hline Nutrutional value & 0.450 & 0.456 & 0.495 & 0.510 \\
\hline Brand & 0.747 & 0.746 & 0.716 & 0.716 \\
\hline Origin & 0.516 & 0.542 & 0.550 & 0.555 \\
\hline
\end{tabular}

Note $={ }^{*}$ variables excluded.

The results of factor loadings and grouping of constructs in the rotation analysis can be seen in Table 3 . The numbers that correspond to factor loadings, defined as the correlation between variables, allow to understand the nature of a particular factor and its variance, i.e., how the variable explains the model (HAIR JUNIOR et al., 2009).

Although the results presented satisfactory factor loadings (above 0.65 ) for the variables; the variables of price (0.91) and fish size (0.83) were discarded because during the construction of the factor design they were isolated, i.e., not grouped in any of the constructs, and not correlating with the other variables.

As shown in Table 3, the factor analysis showed satisfactory factor loadings because they are represented by items with loadings above 0.65 , which suggest the quality of interpretation of each factor (PASQUALI, 2005).

After defining the adjustment that best fits the model (Appendix 1), the Cronbach's Alpha Coefficient test for the entire scale was performed, and the result was 0.72 , and values above 0.60 are considered good (HAIR JUNIOR et al., 2009).

The values of Cronbach's Alpha Coefficient for the constructs quality and consumption were 0.75 and 0.69 , respectively, indicating that the proposed scale has good reliability and internal consistency.

\section{Discussion}

Assessing food consumption is complex due to the various factors involved. In the case of fish, an extra factor must be taken into consideration - its consumption is estimated according to production costs and based on the number of residents of the area. Such estimate may generate systematic errors considering that fish has considerable weight loss until its consumption, either by excess of liquid or ice in the package due to the processing applied such as filleting or other forms of preparation.
Table 3. Rotated matrix (Quartimax) factor loading of the constructs of quality and fish consumption.

\begin{tabular}{lcc}
\hline \multirow{2}{*}{ Items } & \multicolumn{2}{c}{ Constructs } \\
\cline { 2 - 3 } & Quality & Consumption \\
\hline Flavor & & 0.811 \\
Color & & 0.703 \\
Texture & & 0.804 \\
Nutritional value & 0.677 & \\
Brand & 0.656 \\
Origin & 0.667 \\
Stamp of Quality control - SIF & 0.800 \\
"Green" fish & 0.714 \\
\hline
\end{tabular}

Several studies have consistently highlighted the existence of a group of consumers who are concerned about a broad spectrum of issues ranging from the environment and animal welfare to societal concerns including human rights (SHAW et al., 2005).

However, it is extremely important to equate fish consumption with product quality; therefore, this study contributed by proposing an instrument with good statistical indicators that can serve as a basis for future research to evaluate fish consumption in different population groups.

The results concerning the place of consumption reinforces the idea that variables such as culture and reference groups determine the fundamental behavior of purchase and consumption of fish (UILDE; FARAH; FLÁVIA, 2002).

It is important to emphasize the differences between the consumer groups since the understanding and awareness of benefits of fish consumption to health may change the pattern of consumption (DIJK et al., 2011). 
However, consumers tend to be interested in the benefits and method of production of the products they purchase, especially foods (SHAW et al., 2005).

As for purchase of fish, the results of this study are similar to those found by Harris, Knight and Worosz (2006) corroborating that supermarkets may be preferred because of choice options, environment, and quality inspection trust. Furthermore, supermarkets provide more information about the source, sanitation, and hygiene offering the best food safety guarantee.

Consumers associate food safety with healthy food when buying food products (SHAW et al., 2005).

As for the convenience of product, previous studies indicated that the perception of convenience and inconvenience of product among consumers has a negative effect on the frequency of fish consumption (RORTVEIT; OLSEN, 2009; OLSEN et al., 2007).

In the EFA, the isolation of the variables price and size of fish can be justified for corresponding more to characteristics of purchase rather than to consumption, which is not a prevailing characteristic of the subjects studied, mostly students who consume fish at the university restaurant.

The results show two main clusters, the construct "quality", which includes nutritional value, brand, origin, SIF (Quality Control Stamp), and "environment", i.e., characteristics that are associated to the quality of the product. Similarly, the construct "consumption" the following items were grouped together: flavor, color and texture.

This clustering model is interesting because it corresponds to the assumptions of the literature

Health agencies should provide information about consumer's education using several different means of communication (RASPOR, 2006).

Pieniak, Verbeke and Scholderer (2010) suggest that communication itself seems insufficient to allow for more conformity with recommendations; therefore, associating health benefits to fish consumption poses as a more effective method.

The increase in fish consumption also depends on initiatives and improvements of the entire fish sector and should be supported by the fact that fish consumption provides health benefits (MACIEL et al., 2009).

\section{Conclusions}

The proposed instrument designed in this study and the clustering model used corresponded to the assumptions in the literature concerning problems with the production and marketing of fish in the Brazil, which directly affect the quality of the product.

The use of the exploratory factor analysis technique enabled the understanding of how variables are interrelated. Factor analysis allowed the adjustment of the assessment instrument after the removal of variables with low indicators, namely: "Availability in the usual places of purchase", "packaging", and "smell".
Therefore, constructs grouped to assess fish quality based on the results of the rotated matrix were: nutritional value, brand, origin, SIF (Quality Control Stamp), and environment. The variables used to evaluate fish consumption were: flavor, color, and texture.

The results of this study demonstrated that the development of an instrument to evaluate the characteristics involved in the purchase and consumption of fish may help to better understand and propose effective improvements in the production chain of fish taking into account consumer perspectives.

\section{Acknowledgements}

The authors are grateful to the Post-Graduation Program of the Center of Nuclear Energy in Agriculture - CENA - University of São Paulo - Piracicaba - São Paulo state, Brazil and CNPq (National Counsel of Technological and Scientific Development) for the scholarship provided to the first author.

The authors gratefully acknowledge the financial support provided by FAPESP (São Paulo Research Foundation).

\section{References}

ALVES, A. L. S. et al. Padrão alimentar de mulheres adultas. Revista de Saúde Pública, v. 40, n. 5, p. 865-873, 2006. PMid:17301909.

ANASTASI, A.; URBINA, S. Testagem Psicológica. 7. ed. Porto Alegre: ArtMed, 2000. 575 p.

BLANK, L. et al. Community based lifestyle interventions: changing behaviour and improving health. Public Health Nutrition, v. 29, n. 3, p. 236-245, 2007. PMid:17601764. http://dx.doi.org/10.1093/ pubmed/fdm041

BRASIL. Ministério da Pesca e Aquicultura. A campanha vai ressaltar os benefícios do consumo de pescado e o seu preparo. MPA, 2010a. Disponível em: <http://www.mpa.gov.br/mpa/seap/ html/Comercializacao/semana_do_peixe_int2009.html> Acesso em: 25 out. 2010.

BRASIL. Ministério da Pesca e Aquicultura. Consumo Per Capita Aparente de Pescado no Brasil 1996-2009 - O brasileiro está comendo mais pescado. MPA, 2010b. Disponível em: <http:// www.mpa.gov.br/mpa/seap/Jonathan/mpa3/docs/folder\%20 consumo\%20de\%20pescado\%202009\%202.pdf> Acesso em: 02 out. 2010

BURGER, J. Fishing, fish consumption, and awareness about warnings in a university community in central New Jersey in 2007, and comparisons with 2004. Environmental Research, v. 108, n. 1, p. 107-116, 2008. PMid:18632098. http://dx.doi.org/10.1016/j. envres.2008.05.003

COOPER, D. R.; SCHINDLER, P. S. Métodos de pesquisa em administração. 7. ed. Porto Alegre: Bookman, 2003. 640p.

DIJK, H. V. et al. Perceptions of health risks and benefits associated with fish consumption among Russian consumers. Appetite, v. 56, n. 2, p. 227-234, 2011. PMid:21147191. http://dx.doi.org/10.1016/j. appet.2010.12.008

DILLON, W. R.; GOLDSTEIN, M. Multivariate analysis: methods and applications. USA: John Wiley and sons, Inc., 1984. 608 p.

FOOD AND AGRICULTURE ORGANIZATION - FAO. The state of world fisheries and aquaculture (SOFIA): 2008. FAO, 2009. 196 p. 
FIGUEIREDO FILHO, D. B.; SILVA JUNIOR, J. A. Visão além do alcance: uma introdução à análise fatorial. Opinião Pública, v. 16, n. 1, p. $160-185,2010$. http://dx.doi.org/10.1590/S010462762010000100007

HAIR JUNIOR, F. et al. Análise multivariada de dados. 6. ed. Porto Alegre: Bookman, 2009. 688 p.

HARRIS, C. A.; KNIGHT, S.; WOROSZ, M. R. Shopping for food safety and the public trust: What supply chain stakeholders need to know about consumer attitudes. Food Safety Magazine, p. 52-59, 2006. Disponível em: <http://www.foodsafetymagazine.com/articleFF. asp?id=723\&sub=sub1>. Acesso em: 19 mar. 2010.

HONKANEN, P.; OLSEN, S. O.; VERPLANKEN, B. Intention to consume seafood - the importance of habit. Appetite, v. 45, n. 2, p. 161-168, 2005. PMid:16011859. http://dx.doi.org/10.1016/j. appet.2005.04.005

JOHNSON, R. A.; WICHERN, D. W. Métodos mutivariados aplicados de análise de dados. México: International Thomson Editores, 2000.

MACIEL, E. S. et al. Inquérito sobre o consumo de pescado em feira comemorativa da "Semana do Peixe" em cidade do interior de São Paulo. Revista Ciência e Tecnologia - UNIMEP, v. 31, n. 16, p. 59-68, 2009.

MALHOTRA, N. Pesquisa de Marketing uma orientação aplicada. Porto Alegre: Bookman, 2006. 720 p.

MICHELS, I. L.; PROCHMANN, A. M. Estudo das cadeias produtivas de Mato Grosso do Sul: piscicultura. UFMS, 2002.152 p. Disponível em: <http://pt.scribd.com/doc/14791838/Cadeia-Produtiva-DaPiscicultura-Em-MS-2003>. Acesso em: 08 nov. 2010.

MUNÕZ, M. A. et al. Adherence to the Mediterranean diet is associated with better mental and physical health. British Journal of Nutrition, v. 101, n. 12, p. 1821-1827, 2009. PMid:19079848. http://dx.doi.org/10.1017/S0007114508143598

OETTERER, M. Industrialização do pescado cultivado. Guaíba: Editora Agropecuária, 2002. 200 p.

OLSEN, S. O. et al. Exploring the relationship between convenience and fish consumption: A cross-cultural study. Appetite, v. 49, n. 1, p. 84-91. 2007. PMid:17261344. http://dx.doi.org/10.1016/j. appet.2006.12.002

PASQUALI, L. Extração dos fatores. In: PASQUALI, L. (Org.). Análise Fatorial para Pesquisadores. LabPam, 2005. p. 55-86. PMid:16760627.

PIENIAK, Z.; VERBEKE, W.; SCHOLDERER, J. Health-related beliefs and consumer knowledge as determinants of fish consumption. Journal of Human Nutrition and Dietetics, v. 23, n. 5, p. 480-488, 2010. PMid:20831707. http://dx.doi.org/10.1111/ j.1365-277X.2010.01045.x

RASPOR, P. Faces of foods on the world of food systems. Acta Alimentaria, v. 35, p. 247-249, 2006.

RORTVEIT, A. W.; OLSEN, S. O. Combining the role of convenience and consideration set size in explaining fish consumption in Norway. Appetite, v. 52, n. 2, p. 313-317, 2009. PMid:19038300. http://dx.doi.org/10.1016/j.appet.2008.11.001

SCHAWB, A. J. Eletronic Classroom. [online]. Disponível em: $<$ http:// www.utexas.edu/ssw/eclassroom/schwab.html >. Acesso em: 10 set. 2010.

SHAW, D. et al. An exploration of values in ethical consumer decision making. Journal of Consumer Behaviour, v. 4, n. 3, p. 185-200, 2005. http://dx.doi.org/10.1002/cb.3

SONODA, D. Y. Caracterização do mercado de pescado no Brasil. Revista Aquicultura e Pesca, v. 3, n. 28, p. 40-44, jul./ago. 2007.

STATISTICAL PACKAGE FOR THE SOCIAL SCIENCES - SPSS. Base 10.0 User's Guide. Chicago: SPSS, 1999.

TRONDSEN, T. et al. Perceived barriers to consumption of fish among Norwegian women. Appetite, v. 48, p. 301-314, 2003. http://dx.doi. org/10.1016/S0195-6663(03)00108-9

TUU, H. H. et al. The role of norms in explaining attitudes, intention and consumption of a common food (fish) in Vietnam. Appetite, v. 51, n. 13 , p. 546-551, 2008. PMid:18486275. http://dx.doi. org/10.1016/j.appet.2008.04.007

TYROVOLAS, S.; PANAGIOTAKOS, D. The role of Mediterranean type of diet on the development of cancer and cardiovascular disease, in the elderly: a systematic review. Maturitas, v. 65, p. 122-130, 2010. PMid:19656644. http://dx.doi.org/10.1016/j. maturitas.2009.07.003

UILDE, A. G.; FARAH, T. G.; FLÁVIA, M. M. Caracterização do consumo de carnes no Brasil. Revista Nacional da Carne, n. 310, 2002.

VERBEKE, W.; VACKIER, I. Individual determinants of fish consumption: application of the theory of planned behavior. Appetite, v. 44, n. 1, p. 67-82, 2005. PMid:15604034. http://dx.doi. org/10.1016/j.appet.2004.08.006

WEI, X.; ZENG, Y. Consumer's attitudes and willingness-to-pay for Green food in Beijing. 2005. p. 1-10. Disponível em: <http:// sard.ruc.edu.cn/zengyinchu/files/taolunwengao/>. Acesso em: 05 fev. 2011.

ZHOU, J. H. Consumer's attitude, perception and purchase behavior - Case from Jiangsu province. Journal of China Agricultural Economics, v. 11, p. 44-52, 2004. 
Appendix 1. Questionnaire final in the study.

01. Name / contact information (optional): ( ) Employee ( ) Undergraduate ( ) Graduate

02. Age:

03. Marital Status:

( ) Single ( ) Married ( ) Living as married ( ) Separated / Divorced ( ) Widowed

04. You won't consume the flesh of fish:

( ) Once a month ( ) Once a week ( ) Never

( ) Two to three times a month ( ) Two or more times a week

05. If not a fish consumer, why?

( ) Not known ( ) Not available in the usual place of purchase

( ) Price ( ) Has difficulty evaluating the product by appearance

( ) Do not know how to prepare ( ) Health Issues

( ) Do not like ( ) Other reasons. Please specify

06. Where do you usually consume fish?

( ) In your home ( ) In restaurants ( ) At the home of relatives and friends

( ) Student housing ( ) Other

07. When preparing the fish yourself, where do you get the fish from (more often)?

( ) Supermarket ( ) city market ( ) Street market ( ) Other.

( ) Fishery neighborhood ( ) Direct from producer

08. When buying fish, what is your packaging type preference?

( ) in bulk (when the consumer chooses by themselves)

( ) In plastic bags (common packaging) ( ) In trays (with little unity)

09. Your preference regarding the conservation of fish is:

( ) Frozen Product ( ) Cold product

\section{CONSUMPTION}

10. How important do you consider the taste of the fish?

( ) Nothing ( ) Little ( )More or less ( ) Very ( ) Extremely

11. How important do you consider the color of the fish?

( ) Nothing ( ) Little ( )More or less ( ) Very ( ) Extremely

12. How important do you consider the texture / consistency of the fish?

( ) Nothing ( ) Little ( )More or less ( ) Very ( ) Extremely

\section{QUALITY}

13. How would you rate your level of knowledge regarding the nutritional value of fish?

( ) Nothing ( ) Little ( )More or less ( ) Very ( ) Extremely

14. When you buy fish, how important do you consider the brand of the product? ( ) Nothing ( ) Little ( )More or less ( ) Very ( ) Extremely

15. When you buy fish, how important do you consider the origin of the product?

( ) Nothing ( ) Little ( )More or less ( ) Very ( ) Extremely

16. How important do you consider presence of the seal of the Federal Inspection Service - SIF?

( ) Nothing ( ) Little ( )More or less ( ) Very ( ) Extremely

17. How important do you consider the knowledge that the fish was produced without harming the environment?

( ) Nothing ( ) Little ( ) More or less ( ) Very ( ) Extremely 